\title{
Tulane
}

Tulane Economics Working Paper Series

\section{State and Federal Tax Policy toward Nonprofit Organizations}

\author{
James Alm \\ Department of Economics \\ Tulane University \\ jalm@tulane.edu
}

\author{
Daniel Teles \\ Department of Economics \\ Tulane University \\ dteles@tulane.edu
}

Working Paper 1704

Jul 2017

\begin{abstract}
State and federal tax policy in the United States generally favors nonprofit organizations, and particularly nonprofits classified as 501(c)3 nonprofit charities. This favorable tax treatment comes from two types of tax policies. First, nonprofits are exempt from paying a variety of state and federal taxes. Second, individuals are encouraged to donate to nonprofit charities through favorable policies in the federal income tax, state income taxes, and the inheritance tax. This paper presents some basic material on the tax treatment of nonprofit organizations, and then examines what we know and what we do not know about state and federal tax policy toward nonprofit organizations.
\end{abstract}

Keywords: Nonprofit organizations; 501(c)3 organizations; tax deductions; charitable donations; unrelated business income tax; tax price elasticity JEL codes: L3; H24; H31 


\title{
State and Federal Tax Policy toward Nonprofit Organizations
}

\author{
James Alm and Daniel Teles
}

\begin{abstract}
$\underline{\text { Abstract }}$
State and federal tax policy in the United States generally favors nonprofit organizations, and particularly nonprofits classified as 501(c)3 nonprofit charities. This favorable tax treatment comes from two types of tax policies. First, nonprofits are exempt from paying a variety of state and federal taxes. Second, individuals are encouraged to donate to nonprofit charities through favorable policies in the federal income tax, state income taxes, and the inheritance tax. This paper presents some basic material on the tax treatment of nonprofit organizations, and then examines what we know and what we do not know about state and federal tax policy toward nonprofit organizations.
\end{abstract}

Keywords: Nonprofit organizations; 501(c)3 organizations; tax deductions; charitable donations; unrelated business income tax; tax price elasticity.

JEL Codes: L3; H24; H31.

\section{Introduction}

State and federal tax policy in the United States generally favors nonprofit organizations, and particularly nonprofits classified as 501(c)3 nonprofit charities. This favorable tax treatment comes from two types of tax policies. First, nonprofits are exempt from paying a variety of taxes, including the federal corporate income tax (CIT) and many state and local taxes. Second, individuals are encouraged to donate to nonprofit charities through favorable policies in the federal income tax, state income taxes, and the inheritance tax.

In this chapter we present some basic material on the tax treatment of nonprofit organizations and then examine what we know and what we do not know about state and federal tax policy toward nonprofit organizations, both drawing and building upon the analysis by 
Rushton (2010). We do not include discussion of municipal tax policy; for a detailed analysis of these issues, see Sjoquist and Stoycheva (2017).

\section{The current practice of state and federal tax policies toward nonprofit organizations}

A brief description of the nonprofit sector

The United States federal government defines a number of organization types as untaxed nonprofits under Internal Revenue Service (IRS) Code section 501. These organizations are exempt from paying federal corporate income taxes. Simon et al. (2006) suggest that nonprofits can be divided roughly into two groups. The first group, "charitable nonprofit" organizations, includes organizations classified under 501(c)3 of the IRS code. Included in the 501(c)3 category are organizations that provide for: relief for the poor, distressed, or underprivileged; the advancement of religion, education, or science; the erection or maintenance of public buildings, monuments, or parks; a lessening of burdens of government; the promotion of social welfare; the promotion of health; or the fostering of amateur sports competition.

The second group, "noncharitable nonprofit" organizations, includes other nonprofit entities classified under IRS codes 501(c)4 to 501(c)25. The most common of these latter organizations are:

- 501(c) 4 - civic leagues and various advocacy organizations

- 501(c)5 - labor, agricultural or horticultural organizations

- 501(c)6 - business league and chamber of commerce organizations

- 501(c)7 - social and recreational club organizations

- $501(\mathrm{c}) 8$ - fraternal beneficiary societies.

Only the "charitable nonprofits" classified as 501(c)3 organizations are eligible to receive taxdeductible charitable donations, although the nonprofit entities classified under IRS codes 501(c) 4 to 501(c)25 are exempt from many taxes as well. The focus of our discussion is, 
generally, on these many 501(c)3 charitable nonprofit organizations and the wide range of their many economic functions.

While it is a simplification, we can also think about the economic functions of nonprofits (charitable and noncharitable) by a two-fold classification of 501(c) organizations: either as producers of a "public good" or as producers of a "club good". A (pure) public good is both nonrival (e.g., one person's consumption of the good does not diminish another person's consumption of the good) and non-excludable (e.g., an individual cannot be excluded from consuming the good even if he or she does not pay for it). A club good has only the first characteristic; that is, a club good provides a good that is non-rival (at least in the absence of congestion), but individuals who do not contribute toward the good can be excluded from its use. In terms of our two-fold classification, club goods are largely produced by "noncharitable nonprofits", and benefit only their membership. In contrast, public goods produced by "charitable nonprofits" (or "public charities") are both non-rival and non-excludable, and their benefits can be experienced by everyone without any necessary payment by these individuals.

In legal terms, the key provision that qualifies an organization as a nonprofit is that it is subject to the "non-distribution constraint", which requires that any realized profits of the organization must be dedicated to charitable purposes rather than paid to owners or share-holders (Cowan, 2010). Any private benefit to a manager or executive in excess of his or her fair market compensation could cause the organization to face either financial penalties or the loss of nonprofit status. Financial penalties provide for a 25 percent tax, paid by the beneficiary, on the value of excessive benefits and an additional 200 percent tax on the excess benefits if they are not returned to the nonprofit. Additionally, they provide for a tax of 10 percent, up to $\$ 20,000$, on any managers involved in providing the excess benefits. 
As of 2013, there were 1.41 million nonprofit organizations in the United States, of which 954,476 were 501(c)3 public charities. While there were fewer nonprofits in 2013 than prior to the recession - the number of nonprofits fell by 2.8 percent and the number of public charities fell 2.0 percent from 2008 - their total revenue exceeds pre-recession levels, reaching $\$ 1.73$ trillion for public charities and $\$ 2.26$ trillion for the sector as a whole. The majority, 72.0 percent, of the revenue reported by nonprofit charities comes in the form of fees, while donations account for only 13.3 percent of total revenue. These figures are largely driven by the fact that 49.8 percent of all public charity revenue in 2013 accrued to 7,062 nonprofit hospitals and primary care health facilities and an additional 10.8 percent of revenues accrued to the country's 2,050 nonprofit institutions of higher education (McKeever, 2015).

\section{What taxes do nonprofits pay and from which taxes are nonprofits exempt?}

Nonprofits have been exempt from the federal corporate income tax (CIT) since it was first introduced in 1913. However, since 1950 earnings on nonprofits' so-called "unrelated business income" has been subject to the unrelated business income tax (UBIT). UBIT is levied on net revenues earned by nonprofit organizations engaged in activities unrelated to their charitable mission. Congress enacted the UBIT following the donation of the Mueller Macaroni Company to New York University, amid concerns about the effect of untaxed corporations on competition (Rose-Ackerman, 1982).

Cowan (2010) explains the types of activities that are subject to UBIT by way of an example. Consider a performing arts school. This performing arts school is not charged UBIT on income from sales of tickets to performances, but the school would pay UBIT if it earned income by owning and operating a gas station. Passive income (e.g., interest, dividends, capital gains, real property rents) is also generally excluded from UBIT. Finally, the tax code includes three 
additional specific exemptions from UBIT: businesses in which the work is performed by volunteers, businesses that exist for the convenience of members or employees, and thrift stores. IRS regulations require that common costs, or those associated with both the nonprofit's mission and the unrelated business activities, must be allocated between activities (Sansing, 1989).

Nonprofits are generally not exempt from taxes that they pay as employers. For example, they are required to remit federal individual income taxes and federal payroll taxes, and also to pay the employer portions of Social Security and Medicare taxes, all via employer tax withholding (Cowan, 2010).

As for sales taxes, policies for nonprofits vary by state. The majority of states tax sales by nonprofits (with some exemptions), but they exempt sales to nonprofit charities. Forty-five states have a sales tax, and 38 states issue tax exemptions to nonprofits on purchases. Also, 35 states require nonprofits to collect and remit sales taxes on goods sold, with 22 of those states using the IRS definition of charitable nonprofits (Cowan, 2010). Exemptions on goods sold include sales at fundraising events (under some amount), or in conjunction with a specific class or activity (Walker and Sipult, 2011). There are many additional state-specific policies. As an example, Connecticut taxes sales by nonprofits but exempts food products sold by educational institutions to members using prepaid meal plans and sold by hospitals, nursing homes, and day care centers to their clients.

There are several possible justifications for the favorable tax treatment of charitable nonprofit organizations. Hansmann (1981) argues that the exemption from the CIT acts to compensate nonprofits for constraints on capital formation. Hall and Colombo (1991) propose a "donative theory" as a rationale for the exemption. Building on the work of Feldstein (1980), they argue that when a nonprofit receives donations it is evidence that a public good has been 
undersupplied. The exemption therefore acts as a subsidy for a firm that is producing a public good (or, more generally, a good that generates a positive externality), and thereby helps to compensate for individuals' tendencies to be free riders on the charitable contributions of others. Similarly, Cordes (2011) argues that the most persuasive argument for favorable tax treatment is that nonprofits correct private market failures. The nonprofit sector provides an alternative to government production of public goods, as well as a mechanism for the production of club goods and the coordination of advocacy.

The question then arises whether the justifications for the tax exemption extend to profitmaking activities in unrelated business activities. The rationale for UBIT has generally been to prevent unfair competition with the private sector, but critics have argued that it merely moves the unfair competition into markets more closely related with charitable missions (Cowan, 2010). Without UBIT, nonprofits might be given an incentive to wholly own businesses rather than to diversify investments in corporations because wholly owned businesses would not pay any taxes while corporations would pay the CIT (Hansmann, 1989). Sansing (1998) further suggests that the efficiency of UBIT depends on the extent to which the accounting costs of nonprofits correspond to the true economic costs. If the costs are wholly separable, he argues that UBIT acts as a deterrent against the type of inefficient investment put forth by Hansmann (1989). In contrast, inefficiency is created when a nonprofit earns unrelated business income on activities for which it faces an opportunity cost but not accounting costs.

Rose-Ackerman (1982) suggests that the claim of horizontal inequity can also be used to justify UBIT. For example, the pasta maker Ronzoni is at a disadvantage if it pays taxes on income from selling its macaroni products while its competitor Mueller Macaroni Company (who was once owned by New York University) does not. However, Rose-Ackerman (1982) 
notes that the differential tax treatment does not imply that Mueller will offer lower prices. Instead, and continuing the earlier example, Mueller may pass those profits on to New York University.

However, even if the tax code provides advantages to nonprofits, thereby harming forprofit corporations in the process, Rose-Ackerman (1982) dismisses claims that investors have been treated unfairly by describing four scenarios. First, if an industry has perfect competition with easy entry and exit, investors would simply exit the market and make a greater return elsewhere. Second, if exit is difficult but for-profit investors expected nonprofit competition, there is no unfairness because investors had the option of investing in a market without such competition. Third, if competition from nonprofits is unanticipated, it is possible that investors have been harmed, but even in this case, the issue of whether the nonprofits have a competitive advantage is an empirical question to be settled on a case-by-case basis; when a competitive advantage for nonprofits occurs, harm is only caused when nonprofits comprise a significant percentage of the market. Finally, if the market is described by oligopoly, nonprofit competition could harm investors, but those investors had previously benefited from unfair market concentration and as such their claims may be dismissed. Rose-Ackerman (1982) concludes by noting that UBIT creates incentives for market concentration in markets with related charitable missions and so increases the likelihood that, when an unfair advantage arises, harm is necessarily done.

Whether or not UBIT is justified from an efficiency standpoint, it may be beneficial as a tool through which to regulate the nonprofit sector. Rushton (2010) provides the example of collegiate athletics. In 2006, the Ways and Means Committee in the U.S. House of Representatives questioned whether NCAA sports were mission-related activities for nonprofit 
universities. It seems unlikely that a significant amount of revenue would be produced by forcing college sports teams to pay UBIT. Moreover, it is unlikely that that Congress intended, or that a change in tax policy would be able, to cause a market correction that benefited professional sports leagues. Instead, Rushton (2010) argues that Congress used the threat of the policy change as a way to encourage university athletic departments to adhere to charitable, rather than "win-atall-costs", policies. This sort of unofficial regulatory power could be used to police nonprofits in any market.

An alternative argument for the current policy begins by defining the rationale for the CIT itself as tax on the income of shareholders (Rushton, 2007). Nonprofits have been exempt from the CIT from its inception because they have no shareholders. The exemption acts as a subsidy, Rushton (2007) argues, only because of a poorly designed CIT that inefficiently distorts investment decisions. From this viewpoint, UBIT is only necessary to discourage nonprofits from engaging in business activities that are profitable for the nonprofit because the for-profit sector is penalized by inefficiencies in the CIT. Under a more efficient CIT regime, UBIT would be unnecessary.

\section{The tax deduction for charitable contributions}

Additional important aspects of the tax treatment of charitable nonprofit organizations are the ways in which charitable contributions are treated in the federal tax code. Provisions in the personal income tax (PIT), corporate income tax (CIT), estate tax and capital gains tax provide incentives for individuals and businesses to give to charity.

The deduction for charitable giving was added to the PIT in 1917, four years after the introduction of the PIT itself. This tax deduction effectively lowers the price of donations faced by the individual donor, relative to consumption. To illustrate this favorable tax treatment, 
consider the "tax-price" of a donation, $P_{C}$, or the value of the donation minus the tax savings from the donation, expressed per dollar of the donation. For an individual who pays the PIT and who also itemizes charitable deductions, a simplified measure of the tax-price of charity is 1 minus the marginal tax rate, so that $P_{C}=1-\tau_{m}$, where $\tau_{m}$ is the donor's marginal tax rate. ${ }^{1}$ Among high-income taxpayers, the price of giving has varied greatly over time. For example, Bakija and Heim (2011) calculate that the tax-price for millionaires rose from $\$ 0.37$ per dollar of donation in 1979 to $\$ 0.67$ in 1988 , then fell to $\$ 0.63$ in 2006 , and in general has fluctuated with each change in the federal marginal tax rate over the years. As tax rates have fluctuated since the 1970s, charitable donations as a percentage of disposable income have declined among individuals with real incomes over \$200,000 (Bakija, 2011).

. Charitable gifts are exempt from the estate tax (Hanke et al., 2012). In its simplest form, the price of charitable bequests, $P_{C B}$, is defined as $P_{C B}=1-\tau_{e}$, where $\tau_{e}$ is the applicable federal estate tax. However, since the estate tax only affects large non-spousal bequests, for most individuals $\tau_{e}=0 .{ }^{2}$ Federal tax code also encourages individuals to donate assets rather than money by exempting the appreciated value of donated assets from capital gains taxation (Cordes, 2011).

The rationales for these favorable tax treatments vary. The deduction from the PIT was created at its inception to offset any reductions in philanthropy induced by the income tax (Aprill, 2001). Steuerle (2005) views the deduction from the estate tax as a signal by society that the wealthy have an obligation to give back to society, arguing that the estate tax itself has a goal of limiting the concentration of wealth, rather than raising revenue. Exempting donations follows

\footnotetext{
${ }^{1}$ Note that the tax-price of charitable contributions is in general a more complicated expression, dependent upon the marginal tax rate in the federal PIT but also upon the relevant state marginal tax rate and the treatment of capital gains, as discussed later. See Bakija and Heim (2011) for a detailed discussion.

${ }^{2}$ Again, calculation of the tax-price is more complicated (Bakija and Heim, 2011).
} 
because charitable contributions are not part of the tax-base of inheritances concentrated on a few heirs. Another prominent argument has been that the deduction is "efficient" if it leads to an increase in contributions that are greater than the loss in government revenue (Feldstein, 1980; Cordes, 2011). Even if the increase in contributions is not as great as the lost tax revenue, there may still be welfare gains from letting individuals chose which public goods are funded.

A major criticism of these various deductions is their cost. Bakija (2013) estimates that PIT revenue in 2012 was reduced by roughly 4 percent, or $\$ 38$ billion, by the charitable deduction. The most recent estimates from the U.S. Treasury forecast that the deductions will reduce PIT revenue by $\$ 55.4$ billion in 2017 , with an additional cost of $\$ 2.9$ billion in reduced CIT revenue (Office of Tax Analysis, 2016).

An additional criticism is that the benefits of these deductions and exemptions accrue disproportionally to the wealthy. The PIT deduction for charitable giving only applies to individuals who itemize their returns. In 2013, only 29.6 percent of taxpayers itemized their deductions, while 69.0 percent took the standard deduction and were thus unable to take advantage of the tax deduction for charitable giving (IRS, 2016). Individuals who itemize their returns are likely to have higher incomes than non-itemizers (Bakija, 2013). Even among itemizers, the subsidy rises with the donor's marginal tax rate, so that higher income individuals receive a higher subsidy rate. A similar issue arises with the estate tax. Since it only applies to the largest bequests, only the wealthiest families benefit from the deduction for charitable bequests.

\section{What we know: Some areas of general agreement from previous research}

The price elasticity of charitable giving 
The federal tax deductions for charitable gifts have been the subject of vigorous research. Most studies have focused on calculating the tax-price elasticity of charitable contributions $\left(E_{p}\right)$, defined as $E_{p}=\frac{\% \Delta C}{\% \Delta P_{C}}$, where $\% \Delta C$ is the percentage change in charitable giving and $\% \Delta P_{C}$ is the percentage change in the relevant tax-price, either for the PIT or for the estate tax. Relatedly, researchers have also sought to determine whether or not the exemption is "efficient" (or whether the increase in philanthropy is greater than the cost of lost government revenue). Efficiency depends on the tax-price elasticity of charitable contributions. When $E_{p}$ is less than or equal to negative one, the deduction is considered efficient because the total increase in donations will be greater than the reduction in tax revenue.

As a result, there is general consensus in the economics literature that, when the tax-price elasticity is less than negative one, a tax subsidy for donors is more efficient than a regime of taxes and direct public provision (Roberts, 1987). Implicit in this interpretation of the efficiency rule are the assumptions that the government and the nonprofit sector are equally efficient at producing public goods and that government- and nonprofit-provided public goods are equally desired by consumers. While these assumptions are likely violated in practice, the precept continues to act as a rule of thumb.

There have been numerous studies dedicated to estimating the tax-price elasticity of charitable giving. Peloza and Steel (2005) summarize much of this literature, and provide a metaanalysis of prior estimates of the tax-price elasticity, using studies of both the PIT and the estate tax. Estimates of the tax-price elasticity range from -7.07 to +0.12 , with a weighted average of 1.44 (or of -1.11 if outliers are removed). More recent work by Bakija and Heim (2011) finds evidence that implies an elasticity close to, but less than, negative one. It appears that tax 
deductions for charitable giving are (marginally) efficient, but the range in estimates remains quite large.

There are many explanations for the differences in tax-price elasticity estimates. First, Peloza and Steel (2005) conclude that charitable giving from bequests appears to be more sensitive than other forms of charity; that is, Peloza and Steel (2005) estimate that the average elasticity of bequests is, -1.50 , while they estimate an average elasticity of -1.18 for all other forms of charitable giving. These estimates are consistent with the hypothesis that bequests are more responsive to taxes because bequests are more likely to be carefully planned. In this regard, however, Peloza and Steel (2005) also find that the difference between permanent and transitory changes in tax rates is not statistically significant. Second, as demonstrated by Brooks (2007), there appear to be differences between the tax-price elasticity of giving to different types of charities. Brooks (2007) concludes that contributions to education charities and "combination" charities (such as the United Way) are more affected by changes in the tax-price than contributions to, for example, health organizations. Third, Bakija and Heim (2011) show that different populations are likely to have different price responses. They examine differences by income, and find suggestive if somewhat inconclusive results of different responses by income. Finally, tax-price elasticities may differ depending upon whether the tax-price is increasing or decreasing. For example, in a controlled field experiment, Meier (2007) demonstrates that the decline in giving after a removal of a subsidy was larger than the initial increase in giving generated by the subsidy.

While most research has focused on the impact of the tax deduction on donors, Duquette (2016) uses nonprofit tax filings to examine the impact on the nonprofits themselves. His empirical strategy exploits differences in tax rates across states and around the 1986 U.S. tax 
reform, and he estimates a tax-price elasticity of charitable giving of -4 , a much larger effect than generally found among donors. A possible explanation is that donations to religious organizations, which do not appear in the tax records, are less elastic than donations to public charities. Additionally, Duquette (2016) suggests that high-income donors are more sensitive to changes in tax policy than low-income donors, and high-income donors contribute the majority of funds to public charities.

It is important to recognize that the existing findings on the tax-price elasticity of charitable giving are likely to be specific to the exact features of the tax deduction mechanism. In a series of laboratory experiments, Eckel and Grossman $(2003$, 2006) find that subjects make significantly higher contributions under a regime in which their donations are matched than under rebate subsidy regimes. In their first study, they find elasticities of -0.30 to -0.34 under the rebate and -0.94 to -1.07 under the matching regime (Eckel and Grossman, 2003). In their follow-up study, Eckel and Grossman (2006) find that estimates for the tax-price elasticity under a rebate are consistent with the analysis of U.S. taxpayers (or around -1.2), while estimates of the elasticity in matching regime are twice as high (or around -2.6). These widely varying estimates raise potential concerns about the "external validity" of the laboratory results. Moreover, a large field experiment by Karlan and List (2007) that examined various matching ratios found taxprice elasticities near zero. Karlan and List (2007) found that donors give more when offered a match. However, they also found no difference in donor response when the match ratio changed from $\$ 1: \$ 1$ to $\$ 2: \$ 1$ to $\$ 3: \$ 1$. Using a survey of UK taxpayers, Scharf and Smith (2015) estimate elasticities similar to those found in Eckel and Grossman (2003), -0.11 to -0.36 in the case of a rebate and -1.02 to -1.14 in the case of a match. The extent to which behavioral responses differ when the subsidies are offered by a charity, as in Karlan and List (2007), versus when the 
subsidies are offered by the government, as in Eckel and Grossman $(2003,2006)$ or Scharf and Smith (2015), remains an open question.

\section{Competition between nonprofit and for-profit organizations}

Another important area of research is the effect of tax policy on the interaction between nonprofit and for-profit organizations. In some industries, nonprofits and for-profits compete to provide the same services, and state and federal tax exemptions provide nonprofits a potential competitive advantage. The presence of the UBIT mitigates the favorable tax treatment when the competition arises outside of the nonprofits' mission area. As such, the impact of nonprofit policy on competition appears to vary by industry.

In health care and education, the largest nonprofit sectors in terms of revenue, nonprofits provide mission related services that directly compete with for-profit firms. In these fields, Hansmann (1987) finds evidence that higher tax differentials between nonprofits and for-profits in states and cities tend to be associated with a larger market share by nonprofits. Further evidence, specifically regarding hospitals, is provided by Gulley and Santerre (1993), who find a statistically significant relationship between state corporate tax rates and the market share of nonprofit hospitals.

Nonprofits appear to have some advantages even when engaging in commercial activities unrelated to their mission. Given the complexities involved in differentiating between related and unrelated business activities, including the difficulties involved in allocating for costs between mission-related and commercial activities, many nonprofits are effectively exempt from any tax burden even when engaging in unrelated business activities. Cordes and Weisbrod (1998) find a positive relationship between property and corporate income tax rates and the share of nonprofit income that stems from commercial activities. 
It is important to remember that nonprofits may engage in profit-making commercial activities as a means of providing greater amounts of public goods, rather than of increasing the incomes of managers or share-holders. Moreover, it should also be noted that nonprofits may be limited by their bylaws or by manager preferences from straying too far from mission-related activities. Given these considerations, Cordes and Weisbrod (1998) define a "hurdle rate" as the return that a dollar invested by a nonprofit in a commercial activity must earn in order to justify a nonprofit activity. Insofar as nonprofits are bound to their primary missions, the hurdle rate will rise as the commercial activity deviates from the mission. This framework helps explain the choices nonprofits make about where to enter into new commercial enterprises. Adding, say, a gift shop at a nonprofit museum would have a relatively low hurdle rate, while opening a gas station across the street would have a much higher hurdle rate even if it is more profitable. Changes in tax policy and cost shifting between related and unrelated business activities thus alter the set of activities that exceed this hurdle rate and explain the findings by Cordes and Weisbrod (1998).

\section{What we do not know: Some areas of conflicting results and unexplored questions from}

\section{previous research}

\section{Deductions versus credits?}

One area in which there is a strong theoretical literature but relatively little empirical evidence is in the difference between tax deductions and tax credits as subsidies for charitable giving. The distributional consequences of providing a tax deduction rather than a tax credit have been studied extensively, and this work has generally focused on the fact that a deduction provides a greater incentive to higher-income taxpayers who face a higher marginal tax rate than 
to lower-income taxpayers. However, Roberts (1987) argues that welfare effects alter the distributional impacts; that is, he suggests that the effects of a deduction or a credit include not only the tax savings but also the value of the public goods produced by charity and the increase in taxes (or reduction in public spending) needed to finance the deduction. Also, despite the wealth of theoretical models, it remains to be determined whether the actual, estimated elasticity of giving would be the same under both regimes. The different findings in Eckel and Grossman (2003, 2006) and in Karlan and List (2007) suggest that the price elasticity of giving is not constant across regimes.

Additional empirical work is needed to address this issue. The lack of a counterfactual at the federal level prevents a direct empirical analysis of potential policy changes. Even so, useful research could take the form of laboratory experiments like those of Eckel and Grossman (2003, 2006), or of randomized control trials like those of Karlan and List (2007). On a larger scale, most states provide a mix of credits and deductions to subsidize charitable giving. Analysis of these policies may provide evidence of the differential effects deductions and credits.

\section{The mechanics of UBIT?}

Rushton (2010) notes that there is little research to help answer questions about changes in the treatment of nonprofits under UBIT. Defining unrelated business activity is complex. While there is some understanding of the tax impact in the aggregate, the potential economic impact of regulatory changes around the definition of the tax base warrants further study. As Rushton (2010) argues, questions such as, “...how are 'mission-related' revenues defined; should mission-related revenues always be tax-exempt or subject to certain conditions; and in turn should more sources of nonprofit revenue be subject to UBIT?” remain unanswered.

The drivers of nonprofit tax policy? 
A fertile area for future research is the political economy surrounding nonprofit tax policy. For example, to what extent is U.S. policy a compromise between individuals who want lower taxes and those who want more public goods and services? Policymakers may see tax incentives for charitable giving as a sort of win-win scenario in which they can lower their constituents' tax bills while taking action to increase the production of public goods. Economic theory provides no reason to tie a subsidy for charitable giving directly to the marginal tax rate (Feldstein, 1980; Saez, 2004). Yet, the policy of providing a tax deduction rather than a credit has persisted for nearly a century. A model of political economy might explain how this policy has endured.

Similarly, what are the political factors affecting state government policy choices? State policymakers appear to be driven, at least in part, by a tradeoff between altruism and government finance. During the 1980 s and 1990s, many states ended or limited the tax exemptions on nonprofit hospitals. During this period, hospitals with higher levels of charity care were less likely to lose their exemptions while hospitals with higher revenues and profits were more likely to lose their exemptions. Additionally, states with greater revenue needs were more likely to curtail exemptions for nonprofit hospitals (Barniv, Danvers, and Healey-Burress, 2005). Similarly, states that are more dependent on sales tax revenue appear more likely to tax goods purchased and sold by nonprofits (Walker and Sipult, 2011). A model of this tradeoff could help explain the patchwork of policies found at various levels of government.

\section{What we should expect: Using what we know to discuss policy alternatives}

The wealth of research into the tax-price elasticity of charitable giving provides an avenue for researchers to estimate the effects of a range of alternative polices toward charitable 
giving. Following the Obama Administration's 2009 proposal to cap the charitable deduction in the PIT at 28 percent, Cordes (2011) estimated that the policy would lead to a decline in individual giving of 1.7 to 3.2 percent. More recently, Rosenberg et al. (2014) examined the impact of the proposed Tax Reform Act of 2014, and estimated that the broad restructuring would reduce individual giving by 7.0 to 14.0 percent.

The common theme is that any tax reform plan that lowers the marginal tax rate among high-earners will reduce the incentive produced by the PIT deduction. Replacing the deduction with a credit would divorce the incentive from changes in tax rates. The effect of such a change would almost certainly depend on the exact structure of the credit and on the effect of the credit on the specific behavioral responses from donors, both of which determine the relevant price elasticity of the policy innovation. If the price elasticities under a credit regime are similar to those estimated under current policy, Cordes (2011) estimates that replacing the deduction with a flat tax credit of 12 percent would lead to a decline in individual charitable giving of between 3.2 and 8.7 percent.

One way to create incentives for additional charitable giving would be to provide a tax benefit for donors who do not itemize their tax returns. ${ }^{3}$ Using tax-price elasticities of -0.5 and 1.0, Rosenberg et al. (2016) estimate that an expansion of the charitable deduction to nonitemizers would have increased charitable giving between $\$ 5.0$ and $\$ 10.2$ billion in 2017 while reducing tax revenue by $\$ 9.2$ billion.

Another option would be to allow taxpayers to deduct the value of donations made in between tax filings rather than in the prior calendar year. For example, if an individual filed taxes on April 1 in two consecutive years, then the individual would be allowed to deduct

\footnotetext{
${ }^{3}$ Non-itemizers were allowed to deduct their charitable gifts from their adjusted gross income in 1986, and were able to deduct a portion of their donations between 1982 and 1985 (Rosenberg et al., 2016).
} 
donations from, say, April 2016 through March 2017 rather than donations from January 2016 through December 2016. ${ }^{4}$ Rees-Jones and Taubinsky (2016) argue that this policy would increase charitable giving without changing the structure of the PIT. They point to research on tax salience, inattention, and aversion, which finds that individuals are focused on the present, avoiding tax payments more than maximizing tax refunds, that they lack full understanding of tax policy, and that they disproportionally search for information on tax policy before filing their taxes. We should therefore expect that people are more responsive to tax incentives that are visible, that the individuals understand, and that allow them to act immediately upon when they sit down to pay their taxes. This policy change would then increase the price elasticity of giving and increase total donations.

Steuerle (2005) suggests replacing the deduction of charitable bequests from the estate tax with a credit of approximately one and a half times the tax rate. In his example of a 50 percent estate tax, an individual with a $\$ 1$ billion estate could give $\$ 500$ million each to the government and to his or her heirs, or could give $\$ 750$ million to charity, $\$ 250$ million to the heirs, and pay no estate tax. However, it is unclear whether existing estimates of the tax-price elasticity of bequests would remain constant under a drastic policy change such as this one. A better understanding of donor responses to credits, rather than deductions, would help provide estimates of the impact of this type of plan on both donations and revenue.

\section{Why are there gaps in our knowledge? The roles of theory, data, and empirics}

State policies and data limitations

\footnotetext{
${ }^{4}$ This proposal was included in the America Gives More Act of 2014, which passed the U.S. House of Representatives but which did not become law.
} 
While federal tax policy has been the subject of much research, much less is known about the myriad specific state policies that benefit the nonprofit sector. Many states offer targeted tax credits whose magnitude differs for donations to some classes of nonprofits over others. However, the extensive research on the tax-price of charitable giving has focused on federal policy that treats all charitable giving equally. Recent work by Teles (2016) examines two statelevel tax credit programs. The first policy, Arizona's Working Poor Tax Credit, provides a broadly targeted 100 percent credit with a cap of $\$ 200$ per person. He finds no evidence that this tax credit increased gifts to the targeted charities. In contrast, Teles (2016) finds that the Endow Iowa program, which provides a 25 percent credit on gifts to community foundations up to $\$ 300,000$, produced a 125 percent increase in donations to community foundations.

Further research into state-level targeted subsidy policies is warranted and several empirical questions remain unanswered. First, are donations more price-elastic when the tax credit applies only to a small subset of nonprofits? Second, do targeted tax credits lead to a reduction in donations to nonprofits that do not qualify for the credit? Answering these (and other) questions is difficult for several reasons. One problem is the lack of data surrounding state-level policies. A second and related problem is that estimates of the tax-price elasticity of donations face many econometric difficulties: many taxpayers do not donate to charity, many taxpayers do not itemize their tax returns (and such individuals tend to have lower incomes), and marginal tax rates and income are jointly determined. Studies such as Bakija and Heim (2011) rely on large sample sizes and comparison between donors in different states to address these econometric issues. Even so, state-level econometric analysis of tax returns may not yield strong results. An alternative approach might be for researchers to use experimental methods, either in the lab or in the field, which mimic some of the most common state policies. 
Much of the existing research into federal tax policy has relied upon data collected by the IRS from nonprofit Form 990 returns. Because nonprofits are exempt from the CIT, the IRS only has an incentive to audit nonprofits if they earn unrelated business income or they may be in violation of the nondistribution constraint. This leads to two concerns. First how reliable is the data reported by nonprofits to the IRS? Froelich and Knoepfle (1996) and Gordon et al. (2007) raise a number of concerns with IRS 990 data related to the accounting and reporting practices of nonprofits. Second, will lawmakers continue to believe that collection of this data is worthwhile?

\section{An optimal policy toward nonprofits?}

Does the research suggest that these many state and federal tax benefits for nonprofits are good for society? Certainly, this is a subjective question. However, it is possible to define conditions under which tax policies increase or decrease public welfare. One set of powerful tools are optimal tax policy models, which balance the benefits of public expenditures with the costs of taxation to maximize generalized social welfare functions. Saez (2004) and Diamond (2006) extend models of optimal tax policy to include subsidies (such as tax deductions) for charitable gifts. Saez (2004) derives a formula for the optimal subsidy rate as a function of the price response of contributions, the crowding-out effect of government provision, the redistributive tastes of the government, and the size of the external effect of marginal private contributions. His numerical simulations suggest that a subsidy is optimal but that full tax rate deductibility is overly generous and suboptimal. Diamond (2006) also explores the interaction between subsidies and the level of public good provision as well as the optimal pattern of subsidies by earning level. His analysis shows that both optimal subsidy levels and the optimal 
pattern of subsidies across income groups are highly sensitive to the decision of whether or not to include warm-glow preferences in the model. ${ }^{5}$

More recently, Aronsson, Johansson-Stenman, and Wendner (2016) examine the optimal taxation of charities that act to redistribute resources rather than those that produce public goods. Their model assumes that individuals receive warm-glow utility from giving and disutility (or "stigma") from being a recipient of charity. Moreover, utility is affected by the amount that individuals give or receive relative to the rest of the population. They find that the optimal level of tax (or subsidy) varies with the relative strengths of warm glow and stigma.

Yet, despite the strength of the theoretical analysis, fundamental questions about the nature of giving prevent us from fully deriving optimal policy prescriptions. First, the extent to which donors are motivated by the warm glow from donating versus the benefits of public good production remains an open question. Fortunately, significant research continues in this area, particularly with regards to the interaction between public and private funding of the nonprofit sector (Tinkelman and Neely, 2017). Second, there is the even larger question of how to measure the relative value of public goods. Currently, there is no agreed upon method for comparing, for example, Habitat for Humanity's production of "homes, community, and hope" (http://www.habitat.org/how) with the U.S. Department of Housing and Urban Development's production of "strong, sustainable, inclusive communities and quality affordable homes for all" (http://portal.hud.gov/hudportal/HUD?src=/about/mission). Without a way to determine whether the nonprofit or government sector is more efficient at providing public goods, models of general welfare efficiency and optimal policy remain purely theoretical.

\footnotetext{
5 "Warm-glow" preferences refer to the benefit a donor receives from the value of his or her donation rather than from the value of the goods produced with the donation. Other motivations for giving include "pure altruism" (in which an individual gives solely because he or she values the public good provided by the giving) and "impure altruism" (in which the individual values both the public good itself and the act of giving). See Andreoni (1989, 1990) for analysis and discussion of giving motivated by "warm-glow", "pure altruism", and "impure altruism".
} 


\section{What must be done? Some suggestions for extending the literature}

More research is warranted on the interactions between the for-profit and nonprofit sector. There has been an increased use of natural and field experiments to understand the economic implications of government policies. Research continues to use these techniques to better understand the interaction between policy and donations. It seems likely that these techniques will also prove beneficial in understanding how policy toward nonprofits affects the for-profit sector.

Another potentially useful approach in understanding the role of state and federal tax policies may be to marry economic data with a better understanding of how donors make decisions in the absence of incentives. Ties to community, religiosity, and heterogeneity in innate altruism are all likely to influence charitable decision making. At the same time, the presence of unobserved and non-linear relationships with income will impair our ability to isolate the donor response to price changes empirically (Bakija and Heim, 2011).

In this regard, "behavioral economics" will play a central role. The standard neoclassical economic model of human behavior is based on several main assumptions: individuals are rational, they have unlimited willpower, and they are purely self-interested. While these assumptions may be a useful starting point for the analysis of individual behavior, there is increasing evidence that they are inaccurate and unrealistic depictions of many, perhaps most, individuals. Indeed, there is growing acceptance that individuals deviate in significant ways from these assumptions. As emphasized by Congdon, Kling, and Mullainathan (2011), these so-called "deviations" can be classified into three broad areas: non-standard preferences (like otherregarding preferences), imperfect optimization (stemming from, say, limited computation 
abilities), and bounded self-control (as demonstrated by hyperbolic discounting). These "deviations" are the central focus of "behavioral economics", broadly classified as the application of methods and evidence from other social sciences like sociology, anthropology, and, especially, psychology to economics. At its core is the belief that increasing the realism with which individual behavior is seen will improve the ability to predict behavior and to devise policies.

Behavioral economics has obvious implications for the analysis of state and federal tax policy toward nonprofits. The standard approach to charitable giving is based on the assumption that an individual who gives away some amount of income must benefit in some way from this gift, typically because the public benefits of the gift enter, in some way, into the giver's utility function. However, behavioral economics suggests that giving is an inherently social act, in which the various social interactions become important. As noted by Andreoni and Payne (2013), someone is watching as one makes a gift, people are judging each other's actions, and somebody is asking for the gift. In such a setting, the nature of these social interactions emerges as a major factor in giving, and tax policy can affect these interactions. These interactions are starting to receive attention from researchers, but the ways in which tax policies may affect these interactions remain largely unexplored.

\section{Conclusions: Why do nonprofit charitable organizations matter?}

The effect of tax policy on the nonprofit sector continues to generate interest from economists. While there are some general areas of consensus, there remain many open questions and promising areas for future research. Given the impact that tax policy can have on nonprofits, a better understanding of the economic consequences of these policies will help practitioners to 
better plan for policy changes and to better advocate for policies that benefit the sector. For governments, nonprofits provide an alternative source of public good production. Increased understanding of the effect of tax policy on the nonprofit sector improves the efficiency with which government provides public goods for its citizens.

\section{$\underline{\text { References }}$}

Almond, Douglas, and Xia, Xing (2017). Do nonprofits manipulate investment returns? Economics Letters, 155: 62-66

Andreoni, James (1989). Giving with impure altruism: Applications to charity and Ricardian equivalence. The Journal of Political Economy, 97 (6): 1447-1458.

Andreoni, James (1990). Impure altruism and donations to public goods: A theory of warm-glow giving. The Economic Journal, 100 (401): 464-477.

Andreoni, James, and Payne, Abigail (2013). Charitable giving. In Alan Auerbach, Raj Chetty, Martin Feldstein, and Emmanuel Saez (eds.), Handbook of Public Economics, Volume 5, Chapter 1. Amsterdam, The Netherlands: Elsevier Publishing, 1-50.

Aprill, Ellen P. (2001). Churches, politics, and the charitable contribution deduction. Boston College Law Review, 42: 843-873.

Aronsson, Thomas, Johansson-Stenman, Olof, and Wendner, Richard (2016). Redistribution through charity and optimal taxation when people are concerned with social status. Working Papers in Economics 642. Gothenburg, Sweden: University of Gothenburg.

Bakija, Jon, Gale, William G., and Slemrod, Joel (2003). Charitable bequests and taxes on inheritance and estates: Aggregate evidence from across states and time. NBER Working Paper No 9661. Cambridge, MA: National Bureau of Economic Research.

Bakija, Jon, and Heim, Bradley T. (2011). How does charitable giving respond to incentives and income? New estimates from panel data. National Tax Journal, 64 (2):615-650.

Barniv, Ran, Danvers, Kreag, and Healy-Burress, Joanne P. (2005). An empirical examination of state and local revocations of tax-exempt status for nonprofit hospitals. Journal of the American Taxation Association, 27 (2): 1-25.

Brooks, Arthur C. (2007). Income tax policy and charitable giving. Journal of Policy Analysis and Management, 26 (3): 599-612.

Congdon, William J., Jeffrey R. Kling, and Sendhil Mullainathan (2011). Policy and ChoicePublic Finance through the Lens of Behavioral Economics. Washington, D.C.: The Brookings Institution Press.

Cordes, Joseph J. (2011). Re-thinking the deduction for charitable contributions: Evaluating the effects of deficit-reduction proposals. National Tax Journal, 64 (4): 1001-1024.

Cowan, Mark J. (2010). Nonprofits and the sales and use tax. Florida Tax Review, 9 (13):10771265.

Diamond, Peter (2006). Optimal tax treatment of private contributions for public goods with and without warm glow preferences. Journal of Public Economics, 90 (4): 897-919. 
Duquette, Nicolas J. (2016). Do tax incentives affect charitable contributions? Evidence from public charities' reported revenues. Journal of Public Economics, 137: 51-69.

Eckel, Catherine C., and Grossman, Philip J. (2003). Rebate versus matching: Does how we subsidize charitable contributions matter? Journal of Public Economics, 87 (3): 681-701.

Eckel, Catherine C., and Grossman, Philip J. (2006). Subsidizing charitable giving with rebates or matching: Further laboratory evidence. Southern Economic Journal, 72 (4): 794-807.

Feldstein, Martin (1980). A contribution to the theory of tax expenditures. In Henry J. Aaron and Michael J. Boskin (eds.), The Economics of Taxation. Washington, D.C.: The Brookings Institution, 99-122

Froelich, Karen A., and Knoepfle, Terry W. (1996). Internal Revenue Service 990 data: Fact or fiction? Nonprofit and Voluntary Sector Quarterly, 25 (1): 40-52.

Gulley, O. David, and Santerre, Rexford E. (1993). The effect of tax exemption on the market share of nonprofit hospitals. National Tax Journal, 46 (4): 477-486.

Gordon, Teresa, Khumawala, Saleha B., Kraut, Marla A., and Meade, Janet A. (2007). The quality and reliability of Form 990 data: Are users being misled. Academy of Accounting and Financial Studies Journal, 11: 27-49.

Hall, Mark A., and Colombo, John D. (1991). The charitable status of nonprofit hospitals: Toward a donative theory of tax exemption. Washington Law Review, 66: 307-387.

Hanke, Steven A., Englebrecht, Ted D., Di, Hui, and Bisping, Timothy (2012). A two-state analysis of estate taxes and charitable bequests from the most generous decedents. Advances in Accounting, 28 (1): 38-48.

Hansmann, Henry B. (1981). The rationale for exempting nonprofit organizations from corporate income taxation. The Yale Law Journal, 91 (1): 54-100.

Hansmann, Henry (1987). The effect of tax exemption and other factors on the market share of nonprofit versus for-profit firms. National Tax Journal, 40 (1): 71-82.

Hansmann, Henry B. (1989). Unfair competition and the unrelated business income tax. Virginia Law Review, 75 (3): 605-635.

Internal Revenue Service (IRS), Statistics of Income Division. (2016). Individual income tax returns, 2014. Publication 1304. https://www.irs.gov/pub/irs-soi/14inintaxreturns.pdf.

Karlan, Dean, and List, John A. (2007). Does price matter in charitable giving? Evidence from a large-scale natural field experiment. The American Economic Review, 97 (5): 1774-1793.

McKeever, Bruce S. (2015). The nonprofit sector in brief 2015. Washington, D.C.: Urban Institute

Meier, Stephan (2007). Do subsidies increase charitable giving in the long run? Matching donations in a field experiment. Journal of the European Economic Association, 5 (6): 1203-1222.

Office of Tax Analysis (2016). Tax expenditures. U.S. Treasury. Retrieved from https://www.treasury.gov/resource-center/tax-policy/Documents/Tax-ExpendituresFY2018.pdf

Peloza, John, and Steel, Piers (2005). The price elasticities of charitable contributions: A metaanalysis. Journal of Public Policy \& Marketing, 24 (2): 260-272.

Rees-Jones, Alex and Taubinsky, Dmitry (2016). Tax psychology and the timing of charitable giving deadlines. Tax Policy and Charities Initiative. Washington, D.C.: The Urban Institute.

Rose-Ackerman, Susan (1982). Unfair competition and corporate income taxation. Stanford Law Review, 34: 1017-1039. 
Rosenberg, Joseph, Steuerle, C. Eugene, Ovalle, Jocelyn, and Stallworth, Philip. (2016). The new debate over a charitable deduction for non-itemizers. Tax Policy and Charities Initiative. Washington, D.C.: The Urban Institute.

Rosenberg, Joseph, Steuerle, C. Eugene, Steele, Ellen, and Eng, Amanda (2014). Preliminary estimates of the impact of the Camp tax reform plan on charitable giving. Washington, D.C.: The Urban Institute.

Rushton, Michael. (2007). Why are nonprofits exempt from the corporate income tax? Nonprofit and Voluntary Sector Quarterly, 36 (4): 662-675.

Rushton, Michael (2010). Federal tax policy. In Bruce A. Seaman and Dennis R. Young (eds.), Handbook of Research on Nonprofit Economics and Management, Chapter 20. Northampton, MA: Edward Elgar Publishing, 291-302.

Saez, Emmanuel (2004). The optimal treatment of tax expenditures. Journal of Public Economics, 88 (12): 2657-2684.

Sansing, Richard (1998). The unrelated business income tax, cost allocation, and productive efficiency. National Tax Journal, 51 (2): 291-302.

Scharf, Kimberly, and Smith, Sarah (2015). The price elasticity of charitable giving: Does the form of tax relief matter? International Tax and Public Finance, 22 (2): 330-352.

Simon, John, Dale, Harvey, and Chisolm, Laura (2006). The federal tax treatment of charitable organizations. In Walter W. Powell and Richard Steinberg (eds.,), The Nonprofit Sector: A Research Handbook ( $2^{\text {nd }}$ Edition), Chapter 12. New Haven, CT: Yale University Press, 267-306.

Sjoquist, David L., and Stoycheva, Rayna (2017). The property tax exemption for nonprofits. In Bruce A. Seaman and Dennis R. Young (eds.), Handbook of Research on Nonprofit Economics and Management, Chapter 21. Northampton, MA: Edward Elgar Publishing, 303-319.

Steuerle, Gene (2005). Estate tax reform - A third option. Tax Notes (18 July 2005): 343-344.

Tinkelman, Daniel, and Nealy, Daniel G. (2017). Revenue interactions: Crowding out, crowding in, or neither? In Bruce A. Seaman and Dennis R. Young (eds.), Handbook of Research on Nonprofit Economics and Management, Chapter 2. Northampton, MA: Edward Elgar Publishing, 18-41.

Teles, Daniel (2016). Do tax credits increase charitable giving? Evidence from Arizona and Iowa. Tulane University Economics Working Paper 1606. New Orleans, LA: Tulane University.

Walker, Melissa A., and Sipult, Linsey F. (2011). Nonprofit sales tax exemption: Where do states draw the line? Nonprofit and Voluntary Sector Quarterly, 40 (6): 1005-1019.

Weisbrod, Burton A., and Cordes, Joseph J. (1998). Differential taxation of nonprofits and the commercialization of nonprofit revenues. Journal of Policy Analysis and Management, 17 (2): 195-214. 